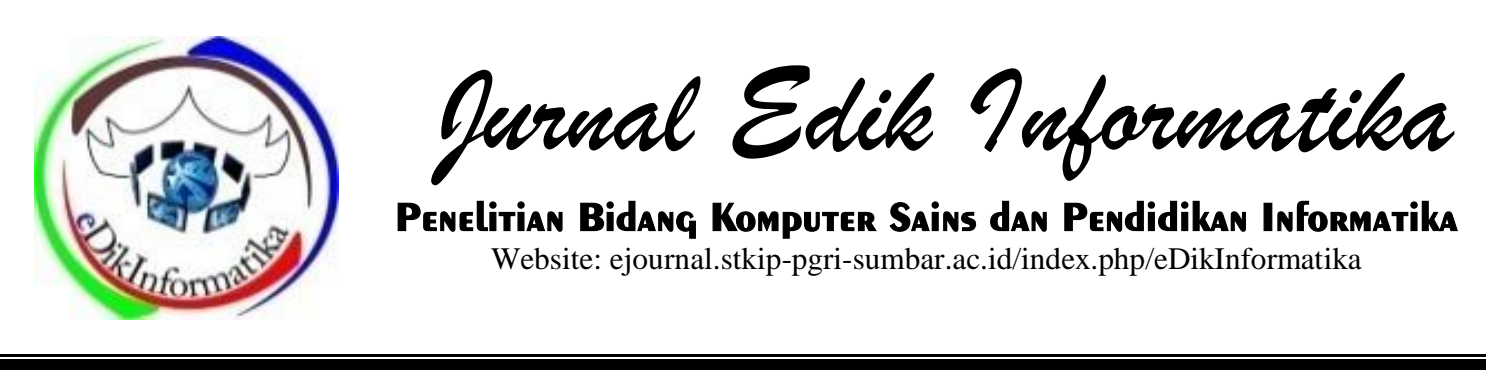

\title{
PERANCANGAN SISTEM INFORMASI REKAM MEDIS PUSKESMAS SUKAMERINDU
}

\author{
Niska Ramadani ${ }^{1}$, Nofri Heltiani ${ }^{2}$ \\ ${ }^{1,2}$ Akademi Kesehatan Sapta Bakti Bengkulu \\ Niskaramadani88@gmail.com, nofrimardhacell@gmail.com
}

INFO ARTIKEL

Diterima:

28 Oktober 2019

Direview:

05 November 2019

Disetujui:

06 Desember 2019

Keywords:

Information Systems, Medical Records, Community Health Center

\begin{abstract}
Sukamerindu Health Center provide services to patients, starting from registration, until the patient receives a prescription drug and the report data processing is still done manually or not yet computerized. Where the patient registration system is recorded in the Register Book, the Community Health Center Management Information System is not yet available, where media for storing patient data and patient medical records are still stored conventionally, resulting in searching for data by searching the medical record files for quite a long time. In the registration is still done by hand where errors can occur recording and making reports related to medical records are still done manually by way of recording patient data, patient visit data that requires a lot of time other than that it is also prone to errors. Medical Record Information System developed using waterfall method and system development tools in the form of context diagrams, DFD, and the proposed database design tool in the form of ERD. Data collection was carried out by interview, observation and literature study. The implementation of the program used in the medical record information system uses the PHP programming language with a MySQL database. The purpose of this study is to design an information system to help reduce problems in the medical record service at Sukamerindu Public Health Center, processing patient data, medical records, has been done computerized so that the process of public health services can be done quickly and easily and avoid mistakes.
\end{abstract}

\section{PENDAHULUAN}

Menurut Peraturan Menteri

Kesehatan Republik Indonesia Nomor

75 Tahun 2014 Puskesmas merupakan fasilitas pelayanan kesehatan yang menyelenggarakan upaya kesehatan masyarakat dan upaya kesehatan perseorangan tingkat pertama di wilayah 
kerjanya. Peranan puskesmas sangat membantu dalam usaha untuk meningkatkan kualitas kesehatan masyarakat. Puskesmas merupakan salah satu instansi yang bergerak dibidang pelayanan jasa kesehatan masyarakat. Pada zaman sekarang telah banyak di bangun Rumah Sakit akan tetapi di daerah pelosok atau desa yang ada masih Puskesmas yang berfungsi sebagai usaha preventif (pencegahan) dan operatif (penanggulangan) terhadap upaya-upaya kesehatan masyarakat. Semakin banyak Rumah Sakit dan Puskesmas yang dibangun maka sangatlah penting jika pihak Puskesmas berfikiran untuk meningkatkan mutu dari Puskesmas tersebut. Untuk menunjang peningkatan mutu Badan usaha sosial seperti Puskesmas yang melayani masyarakat di bidang kesehatan, sistem yang terkomputerisasi sangat diperlukan karena pelayanan yang diberikan di Puskesmas juga harus cepat. Misalnya, mengatasi sistem informasi manajemen pada pendaftaran pasien yang selama ini digunakan. Puskesmas Sukamerindu merupakan salah satu instansi pemerintahan di bidang kesehatan yang peranannya sangat penting dalam meningkatkan kesehatan masyarakat di Kota Bengkulu. Berdasarkan hasil wawancara secara langsung pada kepala puskesmas dalam memberikan layanan rawat jalan pada pasien, untuk pendaftaran pasien masih dilakukan secara manual, dan tidak terekap dengan rapi, sehingga membutuhkan waktu yang lama dalam pelaksanaannya. Salah satu masalah yang sering dihadapi dalam memberikan layanan kepada pasien yaitu proses pelayanan yang membutuhkan waktu yang lama, seperti proses registrasi pasien yang masih manual, dan sering terjadinya duplikat data nomor rekam medis sehingga dibutuhkan sistem yang lebih baik dalam menjalankan proses pelayanan tersebut. Berdasarkan permasalahan ini, perlu dibangun sebuah sistem informasi puskesmas yang dapat digunakan untuk membantu pegawai puskesmas dalam memberikan pelayanan yang lebih baik dalam pengolahan data. Teknologi komputerisasi ini dapat memudahkan pimpinan puskesmas memantau sistem informasi rekam medis melalui laporan yang dihasilkan melalui system. Serta dapat mempermudah petugas dalam melakukan pencatatan data riwayat kesehatan pasien. Selama pasien melakukan pemeriksaan atau menjalani perawatan medis oleh dokter atau suatu instansi medis, maka status kesehatan pasien akan dicatat sebagai data rekam medis pasien. Data rekam medis pasien tersebut dapat dipakai sebagai acuan untuk pemeriksaan kesehatan pasien selanjutnya, sekaligus sebagai bukti tercatat mengenai diagnosis penyakit pasien dan pelayanan medis yang diperoleh.

\section{Tujuan Penelitian}

Tujuan yang akan dicapai dalam penelitian ini adalah sebagai berikut untuk merancangan Sistem Informasi Rekam Medis pada Puskesmas serta, mengimplementasikan system Informasi Rekam Medis Puskesmas.

\section{TINJAUAN PUSTAKA Sistem Informasi}

Sistem merupakan suatu jaringan kerja yang saling berhubungan dan berkumpul bersama-sama untuk mencapai suatu jaringan tertentu. Sedangkan Informasi adalah data yang diolah menjadi bentuk yang lebih berguna dan lebih berarti bagi yang menerimanya. Oleh karena itu, Sistem informasi dapat didefinisikam sebagai kumpulan elemen yang saling berhubungan satu sama lain yang 
membentuk satu kesatuan untuk mengintegrasikan datamemproses dan menyimpan serta mendistribusikan informasi.

\section{Konsep Dasar Sistem}

Terdapat dua kelompok pendekatan sistem yang menekankan pada prosedurnya dan yang menekankan pada komponen atau elemennya, yaitu :

a. Pendekatan sistem yang lebih menekankan pada prosedur. Mendefinisikan sistem sebagai suatu jaringan kerja yang dari prosedurprosedur yang saling berhubungan, berkumpul bersama-sama untuk melakukan suatu kegiatan atau untuk menyelesaikan suatu sasaran tertentu.

b. Pendekatan sistem yang lebih menekankan pada elemen atau komponennya.

c. Mendefinisikan sistem sebagai suatu kumpulan dari elemenelemen yang berinteraksi untuk mencapai suatu tujuan tertentu.

\section{Rekam Medis}

Menurut Peraturan Menteri Kesehatan Nomor 269/MENKES/PER/III/2008 rekam medis adalah berkas yang berisikan catatan dan dokumen tentang identitas pasien, pemeriksaan, pengobatan, tindakan dan pelayanan lain yang telah diberikan kepada pasien. Dalam pengobatan baik yang dirawat inap, rawat jalan maupun yang mendapatkan pelayanan gawat darurat rekam medis mempunyai pengertian yang sangat luas, tidak hanya sekedar kegiatan pencatatan, akan tetapi mempunyai pengertian sebagai suatusistem penyelenggaraan rekam medis yaitu mulai pencatatan selama pasien mendapatkan pelayanan medis, dilanjutkan dengan penanganan berkas rekam medis yang meliputi penyelenggaraan penyimpanan serta pengeluaran berkas dari tempat penyimpanan untuk melayani permintaan atau peminjaman apabila dari pasienatau untuk keperluan lainnya rekam medis mempunyai dua bagian yang perlu diperhatikan yaitu :

1. Bagian pertama adalah tentang Individu :suatu informasi tentang kondisi kesehatan dan penyakit pasien yang bersangkutan dan sering disebut Patient Record

2. Bagian kedua adalah tentang manajemen: suatu informasi tentang pertanggungjawaban apakah dari segi manajemen maupun keuangan dari kondisi kesehatan dan penyakit pasien yang bersangkutan rekam medis juga merupakan kompilasi fakta tentang kondisi kesehatan dan penyakit seorang pasien yang meliputi : Data terdokumentasi tentang keadaan sakit sekarang dan waktu lampau dan pengobatan yang telah dan akan dilakukan oleh tenaga kesehatan profesional secara tertulis.

\section{Tujuan dan Kegunaan Rekam Medis}

Departemen Kesehatan Republik Indonesia telah mengeluarkan peraturan Menteri Kesehatan Nomor 269/MENKES/PER/III/2008 tentang rekam medis yang bertujuan agar terciptanya keseragaman dalam persepsi dan pelaksanaan rekam medis di setiap institusi pelayanan kesehatan, dalam hal tata cara penyelenggaraan, pemilikan dan pemanfaatan isi Rekam Medis, pengorganisasian dan sanksi jika terjadi pelanggaran dalam pelaksanaan. Tanpa didukung suatu sistem pengelolaan rekam medis yang baik dan benar, maka tertib administrasi tidak akan berhasil. Kegunaan Rekam Medis antara lain :

1. Aspek administrasi, suatu berkas rekam medis mempunyai nilai administrasi, karena isinya menyangkut tindakan berdasarkan wewenang dan tanggung jawab sebagai tenaga medis 
2. Perawat dalam mencapai tujuan pelayanan kesehatan. Aspek medis, catatan tersebut dipergunakan sebagai dasar untuk merencanakan pengobatan /perawatan yang harus diberikan kepada pasien.

3. Aspek hukum, menyangkut masalah adanya jaminan kepastian hukumatas dasar keadilan, dalam rangka usaha menegakkan hukum sertapenyediaan bahan tanda bukti untuk menegakkan keadilan.

4. Aspek keuangan, isi rekam medis dapat dijadikan sebagai bahan untukmenetapkan biaya pembayaran pelayanan. Tanpa adanya bukti catatantindakan/pelayanan, maka pembayaran tidak dapat dipertanggunjawabkan.

5. Aspek penelitian, berkas rekam medis mempunyai nilai penelitian,karena isinya menyangkut data/informasi yang dapat digunakan sebagai aspek penelitian

6. Aspek pendidikan, berkas rekam medis mempunyai nilai pendidikan, karena isinya menyangkut data/informasi tentang kronologis daripelayanan medik yang diberikan pada pasien

7. Aspek dokumentasi, isi rekam medis menjadi sumber ingatan yang harusdidokumentasikan dan dipakai sebagai bahan pertanggungjawaban danlaporan sarana kesehatan.

Berdasarkan aspek-aspek tersebut, maka rekam medis mempunyai kegunaan yang sangat luas yaitu :

a. Sebagai alat komunikasi antara dokter dengan tenaga kesehatan lainnya yang ikut ambil bagian dalam memberikan pelayanan kesehatan. b. Sebagai dasar untuk merencanakan pengobatan/perawatan yang harus diberikankepada seorang pasien.

c. Sebagai bukti tertulis atas segala tindakan pelayanan, perkembangan penyakit dan pengobatan selama pasien berkunjung/dirawat di Rumah Sakit.

d. Sebagai bahan yang berguna untuk analisa, penelitian dan evaluasi terhadap program pelayanan serta kualitas pelayanan.

e. Melindungi kepentingan hukum bagi pasien, sarana kesehatan maupun tenaga kesehatan yang terlibat.

f. Menyediakan data dan informasi yang diperlukan untuk keperluan pengembangan program , pendidikan dan penelitian

g. Sebagai dasar di dalam perhitungan biaya pembayaran pelayanan kesehatan.

h. Menjadi sumber ingatan yang harus didokumentasikan serta bahan pertanggungjawaban dan laporan.

\section{METODE PENELITIAN}

Rancangan penelitian ini adalah evaluasi dan pengembangan sisten dengan mengunakan PHP dan MySQL. Obyek penelitian ini adalah system pelayanan rekam medis di Puskesmas Sukamerindu dan sebagai subyeknya adalah petugas rekam medis. Teknik pengumpulan data dengan wawancara dan studi pustaka. Sedangkan untuk metode pengembangan perangkat lunak dengan metode waterfall. Implementasi sistem dilakukan dengan menggunakan bahasa pemrograman PHP dengan Pengolahan Data Menggunakan MySQL. Dan keempat tahap testing, pada tahap ini dilakukan pengujian perangkat lunak untuk 
memastikan semua persyaratan sistem telah terpenuhi dan memastikan bahwa keluaran memberikan hasil yang sesuai dengan kebutuhan. Dalam penelitian ini pengujian sistem dilakukan menggunakan pengujian black-box.

\section{HASIL DAN PEMBAHASAN}

1. Mengidentifikasi, Seleksi, dan Perencanaan Sistem Informasi Rekam Medis

Pengolahan data pasien pada Puskesmas Sukamerindu masifh dilakukan secara manual, dimana data pasien di tulis pada buku register, belum tersedianya sistem informasi manajemen puskesmas yang berbasis elektronik, sehingga sering terjadi kesalahan dalam pengolahan data pasien. Oleh karena itu perlu dilakukan perencanaan untuk pengembangan sistem informasi rekam medis. Adapun perencanaan dalam perancangan sistem informasi rekam medis pada puskesmas sukamerindu meliputi beberapa perencanaan kebutuhan, di antaranya:

a. Kebutuhan software

Dalam perancangan sistem informasi di butuhkan beberapa software pendukung diantaranya:

1) Sistem Operasi Microsoft Windows 7

Ultimate.

2) Case studio untuk membuat Context Diagram, DFD dan ERD.

3) PHP dan MySQL

4) Microsoft Visio 2007 untuk membuat Dokumen Flow dan System Flow.

b. Hardware Pendukung Adapun hardware yang di pergunakan guna mendukung perangkat lunak dalam merancang sistem informasi sensus harian di rumah sakit bhayangkara ini diantaranya:

1) Personal komputer (Laptop) dengan intel "pentium" processor T4300

2) $1,800 \mathrm{MHz} F S B$ 2) VGA $32 \mathrm{MB}$ bit

3) 1 GB Memory

4) 14.0 inchi HD LED

5) 250 GB Harddisk

c. Kebutuhan Pengguna atau User Adapun perancangan sistem informasi yang di buat akan di pergunakan oleh:
1) Petugas
Pendaftaran
Ruangan sebagai pendukung dalam melakukan pekerjaan sehari hari dalam mendaftarkan pasien
2) Programer sebagai bahan acuan dalam pembuatan aplikasi sistem informasi rekam medis Puskesmas

d. Kebutuhan pengguna sistem Informasi

Kebutuhan informasi yang diinginkan baik bagi bagian pendaftaran sebagai pengelola informasi dan laporan. bagi rekam medis sebagai penerima informasi serta bagian-bagian lain yang terlibat adalah suatu suatu informasi yang terkait dalam pelaksanaan pemeriksaan dan pembuatan laporan yang mampu menampilkan informasi yang lebih cepat dan penerbitan laporan lebih akurat

e. Kendala sistem informasi

Pemberian informasi pada pengolahan data di bagian pendaftaran masih di proses secara manual. Sehingga kebutuhan yang diperlukan dalam proses pengurusan seperti 
menginput data pasien dan rekapitulasi jumlah kunjungan pasien memerlukan waktu yang relatif lama. Adapun kendala kendala yang di maksud adalah: 1) Data (data disimpan dengan format yang sudah di tentukan Puskesmas) yang satu dengan yang lainnya tidak terhubung sehingga menyulitkan pegawai untuk melakukan verifikasi dan validasi data pada saat pembuatan laporan. 2) Dokumen fisik disimpan secara manual dengan sistem penyimpanan terpisah. 3) Keterbatasan pegawai yang terkadang lupa menginputkan data.

f. Kelayakan sistem informasi

1. Kelayakan sarana dan prasarana sebagai berikut: Diunit Pendaftaran sudah ada 1 unit komputer, perlu di tambah 4 unit komputer untuk di tempatkan di tiap poli yang dapat mendukung penggunaan sistem informasi yang akan dibuat.

2. Kelayakan sumber daya manunsia

Dibagian unit rekam medis dan rekapitulasi terdapat staf yang sudah terbiasa mengoprasikan komputer. Untuk memperlancar sistem untuk di jalankan minimal di butuhkan 4 lulusan rekam medis yang akan di tempatkan di tiap poli, untuk mengoperasikan sistem informasi dan 5 orang lulusan rekam medis di unit rekam medis.

3. Kelayakan hukum Sistem informasi ini dibangun secara legal karena tidak merugikan pihak manapun.

2. Analisis Sistem

Analisis sistem (systems analysis) dapat didefinisikan sebagai penguraian dari suatu sistem informasi yang utuh ke dalam bagianbagian komponennya dengan maksud untuk mengidentifikasikan dan mengevaluasi permasalahanpermasalahan, kesempatankesempatan,hambatan-hambatan yang terjadi dan kebutuhankebutuhan yang diharapkan sehingga dapat diusulkan perbaikannya. Pada bagian analisa ini peneliti akan menganalisis sistem lama dari Puskesmas Sukamerindu. Desain sistem terdiri dari desain sistem lama kemudian setelah di analisis akan terbentuk desain sistem baru (alternative) yang pada dasarnya memiliki kesamaan Desain sistem Lama dan desain sistem alternative yang dicantum dalam gambar DFD dibawah ini:

A. Diagram Konteks

Diagram Konteks Untuk membatasi sistem yang menunjukan adanya interaksi sistem dengan komponen luar sistem maka perlu dibuat diagram konteks yang merupakan suatu diagram yang menggambarkan sistem dalam satu lingkungan dan hubungan dengan entitas luar. Diagram konteks aplikasi ini menggambarkan sistem aliran program secara umum. 


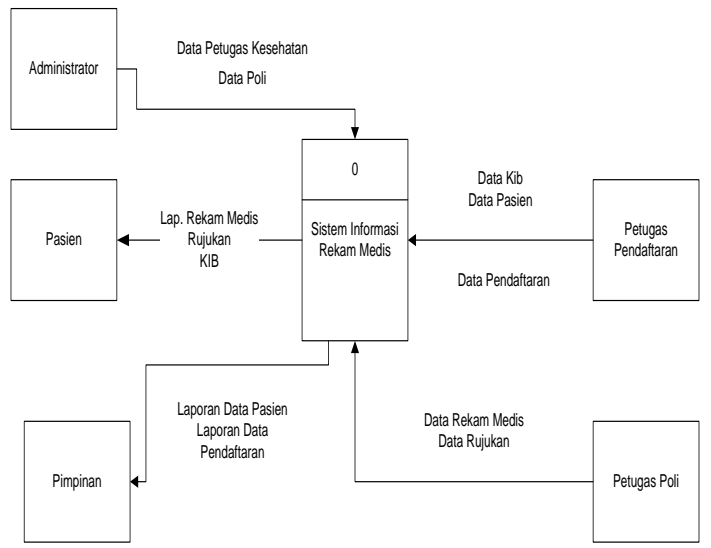

Gambar 1. Diagram Konteks

\section{B. Diagram Alir Data Level 0}

\section{Pada Sistem Rekam Medis}

Puskesmas Sukamerindu pengolahan data terdir atas input data, pengolahan data, dan laporan yang diambil dari penginputan data pasien, data pendaftaran, dan daftar poli yang dituju. Setelah petugas pendaftaran menginputkan data pasien, data pendaftaran, dan mendapatkan pelayanan, maka petugas poli menginputkan data rekam medis pasien ke dalam sistem. Untuk Kepala Puskesmas mendapat semua laporan dari sistem rekam medis Puskesmas Sukamerindu.

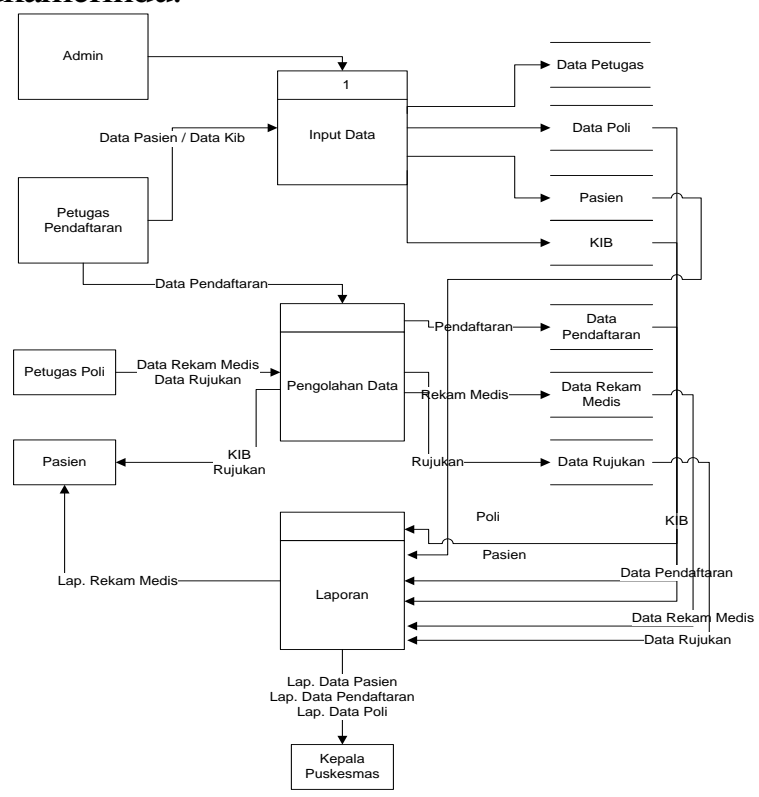

Gambar 2. Data Flow Diagram Level 0
C. Entity Relationship Diagram

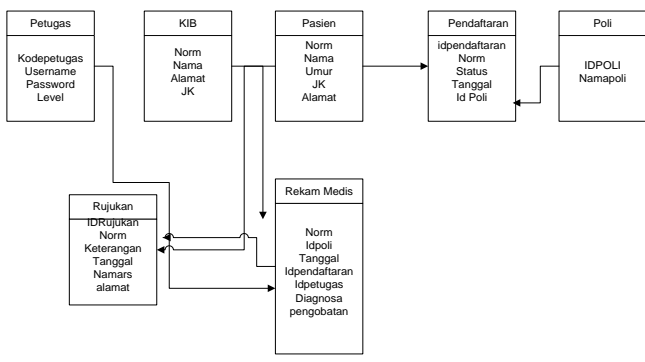

Gambar 3. Entity Relationship Diagram

2. Implementasi

Dari analisa perancangan yang telah dilakukan, maka implementasi dari sistem informasi rekam medis puskesmas sukamerindu adalah sebagai berikut :

a. Form Log In

Form Log In digunakan untuk input username dan password agar bias mengakses sistem informasi rekam medis. Dengan menginputkan username, password, serta level hak akses pada sistem.

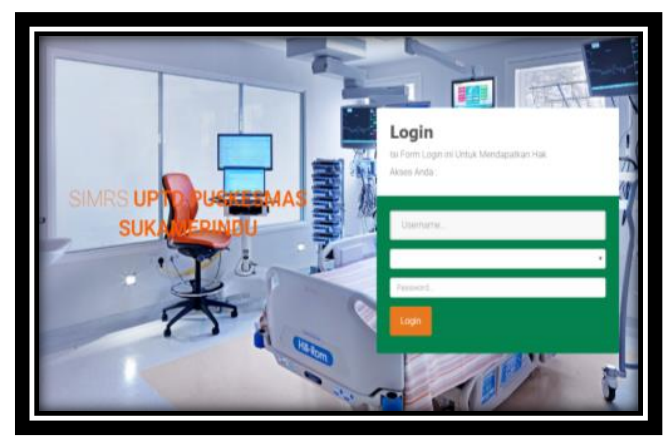

Gambar 4. Form Login

b. Form Utama

Menu utama dibagi menjadi beberapa sub menu diantaranya adalah : proses, Laporan, master, sistem dan exit. 


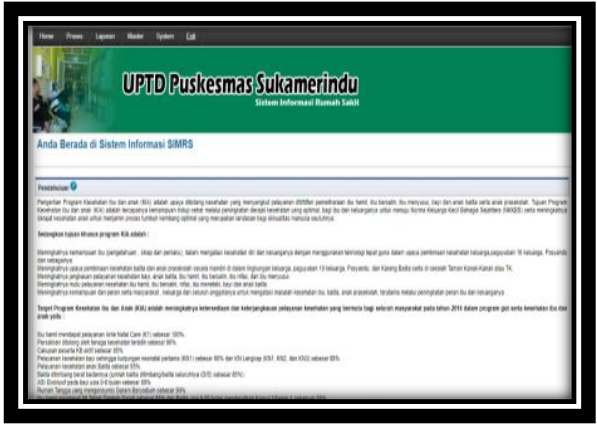

Gambar 4. Menu Utama

c. Form Input Data Pasien

Form data pasien digunakan untuk menginput data pasien baru, dengan mencantumkan nama, tempat lahir, alamat, jenis kelamin, umur. Dan data identitas lainnya

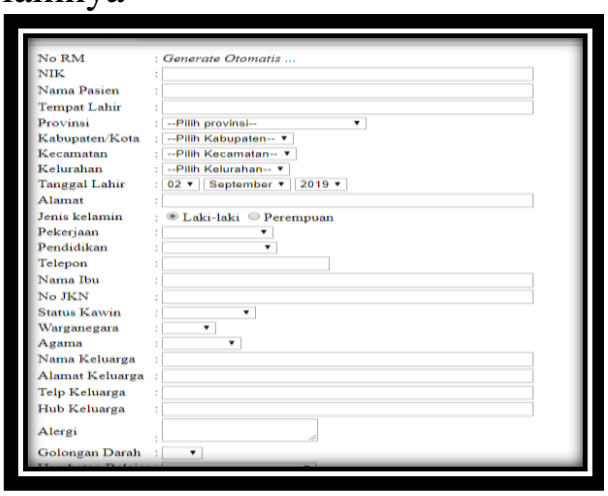

Gambar 5. Form Input Data Pasien

d. Form Input Data poliklinik

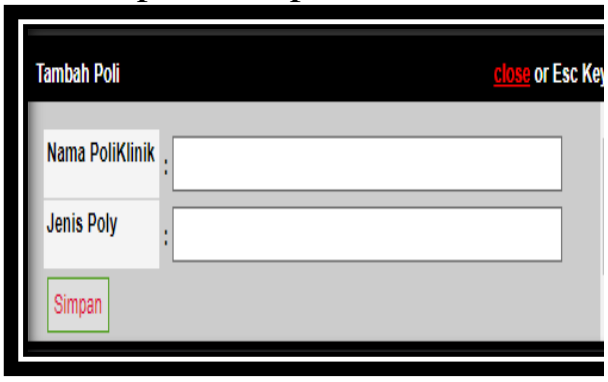

Gambar 6. Form Input Data Poli

e. Form Registrasi/ Pendaftaran

Form Registrasi digunakan untuk menginpt Data Pendaftaran pasien berdasarkan tanggal kunjungannya.

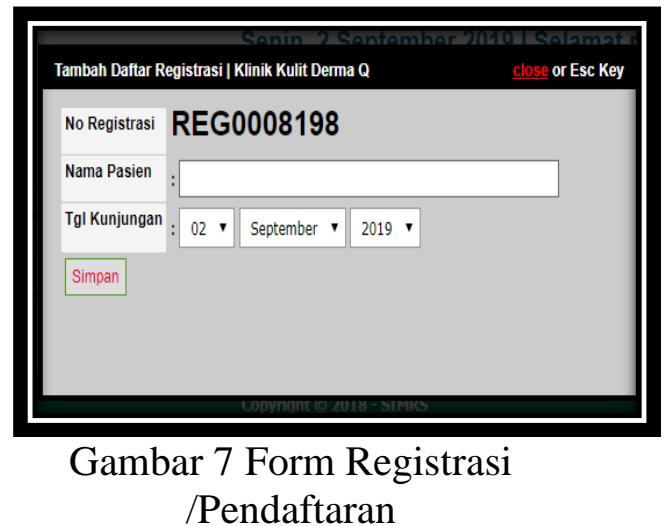

f. Form Rekam Medis Pasien

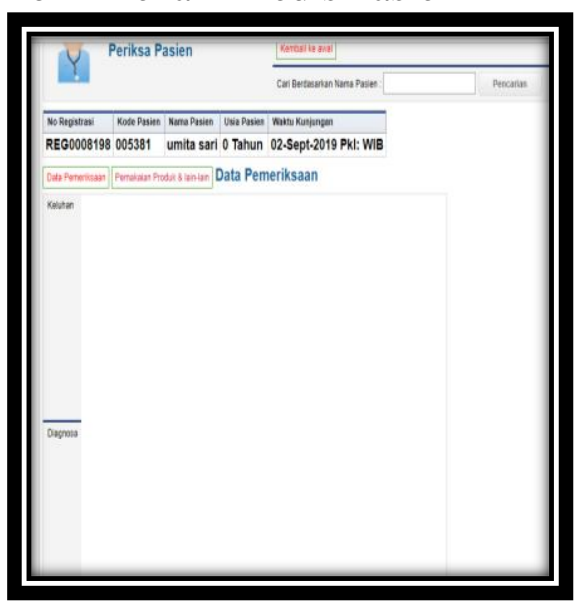

Gambar 8. Form Rekam Medis

\section{g. Form Cetak Laporan}

1. Pilih menu laporan kemudian klik pada laporan kunjungan perperiode, Pada tampilan yang muncul isi tanggal, kelompok pasien, dokter, dan pelayanan kemudian klik cari rekap.

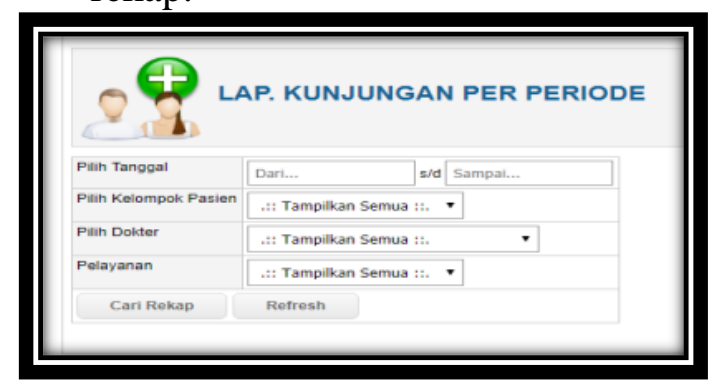

Gambar 9. Laporan Proses 1 
2. Kemudian setelah keseluruhan laporan muncul maka klik "cetak" untuk mencetak laporan.

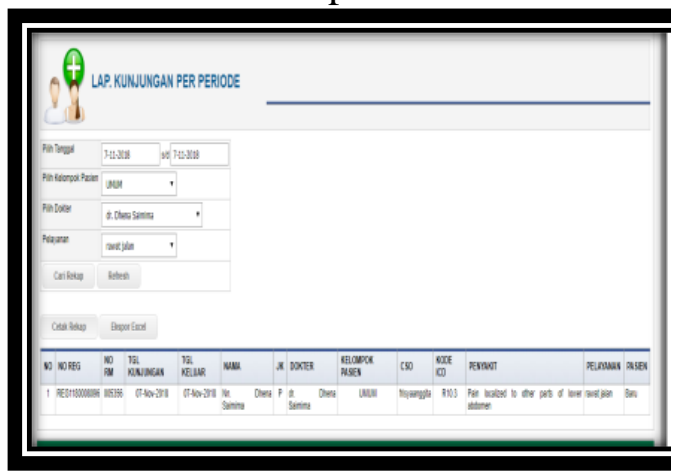

Gambar 10. Laporan Proses 2

3. Setelah klik "cetak rekap" makan akan muncul tampilan berikut dan laporan siap di cetak.

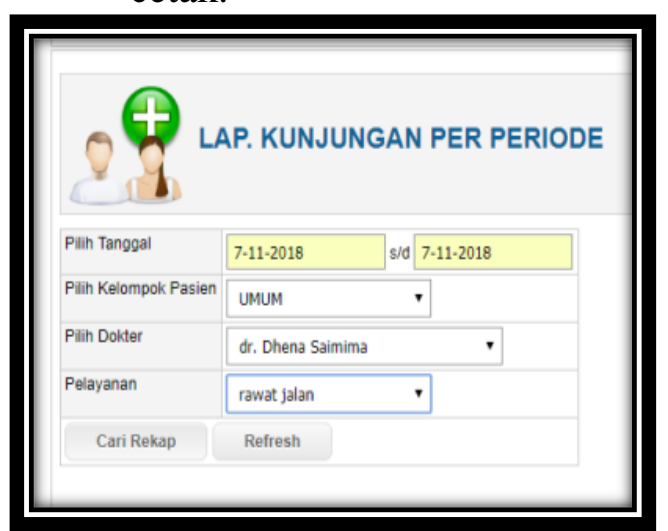

Gambar 10. Laporan Proses 3

4. Setelah selesai keluar dan klik menu exit.

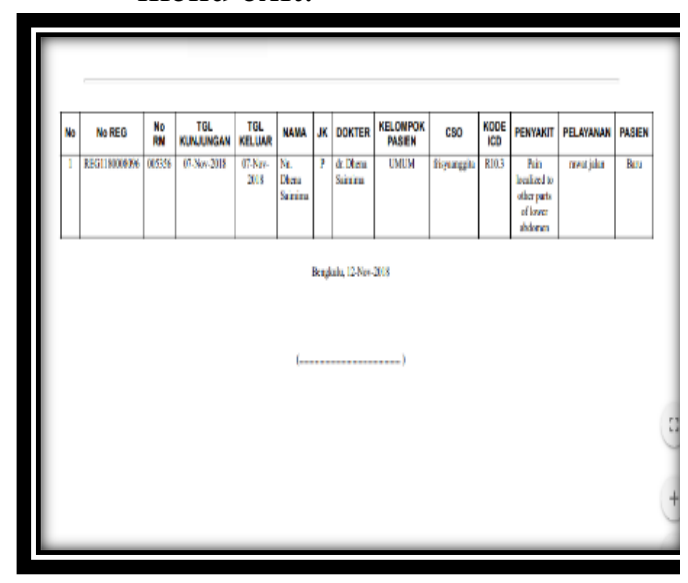

Gambar 9. Laporan Kunjungan

\section{KESIMPULAN DAN SARAN Kesimpulan}

Berdasarkan hasil ujicoba sistem informasi rekam medis pada Puskesmas Sukamerindu Kota Bengkulu dan data serta informasi yang telah dikumpulkan, dapat disimpulkan bahwa :

1. Program yang dibangun mudah untuk dipergunakan,tidak membutuhkan keahlian dan keterampilan khusus dalam menjalankannya.

2. Program ini dapat memberikan kemudahan bagi UPTD Puskesmas Sukamerindu dalam pelaksanakan kegiatan rutin pelayanan pendaftaran pasien.

\section{DAFTAR PUSTAKA}

Cahyanti, Ana Nur. (2012). Pembangunan Sistem Informasi Manajemen Puskesmas PakisBaru Nawangan. Journal Speed Volume 4 No. 4

Buliali, Joko Lianto.(2007).Sistem Pencatatan Informasi Medis Berbasis Teknologi Microsoft .Net . Jurnal Informatika, Vol. 3 No.1. Juni 2007:97-118

Nurdiansyah Susanto, Gunawan. Sistem Informasi Rekam Medis Pada Rumah Sakit Umum Daerah RSUD) Pacitan Berbasis Web Base. Journal Speed .Volume 3 No 4 - 2011 - ijns.org Permenkes

Deni sutaji, Sistem Inventory Mini Market Dengan PHP dan Jquery-Cet I. Penerbit Lokomedia, Yogyakarta, 2012.

MADCOMS, PHP dan MySQL untuk Pemula Edisi 1. Penerbit Andi, Yogyakarta, 2008

Menkes RI. 2008. Peraturan Menteri Kesehatan RI Nomor 269/MENKES/PER/III/2008 tentang Rekam Medis. 
Sundari, Jenie . (2016). Sistem Informasi Pelayanan Puskesmas Berbasis Web. ijse.bsi.ac.id .Volume 2 No 1 2016 . 